\title{
Shelf Life Enhancement of Custard Apple (Annona squamosa L.) under
} Sub-Tropical Conditions of Garhwal Hills

\author{
Tanuja $^{1}$, D. K. Rana ${ }^{1}$ and D. S. Rathi ${ }^{2 *}$ \\ ${ }^{1}$ HNB Garhwal Central University, Department of Horticulture, Srinagar (Garhwal) 246174, \\ Uttarakhand, India \\ ${ }^{2}$ G B Pant University of Agriculture and Technology, Pantanagar, 263153, \\ Uttarakhand, India \\ *Corresponding author
}

Keywords

Custard apple, Physiological loss in weight (PLW), Polypropylene bag

Article Info

\section{Accepted:}

22 January 2021

Available Online:

10 February 2021
An experiment was conducted at Horticultural Research Centre, Chauras, HNB Garhwal University, Srinagar Garhwal, Uttarakhand, India during autumn season 2017. The present investigation on improvement of shelf life of custard apple (Annona squamosa L.)cv. Balanagar was conducted with treatment having polypropylene bags with different number of holes. The experimental results showed that significantly lowest physiological loss in weight $(1.27 \%)$ was recorded under the treatment $\left(\mathrm{T}_{3}\right)$ having 24 holes in polypropylene bag while highest physiological loss in weight $(2.42 \%)$ was noted with the treatment $\left(\mathrm{T}_{8}\right)$. Significantly highest TSS $\left(25.98^{\circ}\right.$ Brix) was estimated in polypropylene bags with 24 holes $\left(\mathrm{T}_{3}\right)$ treatment and lowest TSS $\left(20.78^{\circ}\right.$ Brix) were recorded under control $\left(\mathrm{T}_{8}\right)$. The highest total sugar $(20.59 \%)$ was found in the treatment $\left(\mathrm{T}_{3}\right)$ whereas treatment $\mathrm{T}_{8}$ showed the lowest total sugar $(16.66 \%)$.

\section{Introduction}

Custard apple (Annona squamosa L.) is a climacteric fruit, semi deciduous, exotic subtropical fruit, highly perishable in nature and consumed in many countries throughout the world. Hence, it is mostly utilized or preferred for fresh market. Due to its climacteric nature, it ripens fast and spoiled easily (Manica, 1994). It belongs to the family
Annonaceae, is believed to be introduced in India from tropical South America (Beerh, 1972), and is widely distributed throughout the tropical and sub-tropical regions. It has several synonymous such as Sithaphal, Sharifa, Sugar apple, Sweet sop etc. and more than 70 species come under the genus Annona of which only six of them produces edible fruits. Custard apple is the rich source of nutrients but it has short storage life and 
having a great demand in the market. In India, custard apple is grown on marginal lands and hilly rocks with minimum inputs (Rajput, 1985). It is grown in Andhra Pradesh, Assam, Bihar, Gujarat, Karnataka, Kerala, Madhya Pradesh, Maharastra, and Punjab, Rajasthan, Tamil Nadu, Uttar Pradesh and West Bengal states. Besides India, it is common in China, Philippines and Cuba and has a commercial importance in Egypt and Central Africa. The plants are hardy and drought resistant and can thrive well on marginal and neglected soils (Rajput, 1985). Custard apple is a climacteric fruit and starts ripening soon after detachment from the tree (Wills et al., 2001). It is highly perishable fruit with short shelf life of 1 to 2 days after ripening. The steady increase in area under custard apple has enhanced the fruit flow into the markets which most of the time leads to glut in the markets (Jalikop, 2006). The lack of information on the postharvest handling of this highly perishable fruit has resulted in huge losses. Extension of shelf life in custard apple even for a day or two will go a long way in increasing the shelf life and thus making it much easier to handle the fruit. The practice as reported by Salunkhe and Kadam (1995) and Reddy (2000) suggest that the fruits of custard apple after harvesting are either loaded directly or packed in bamboo baskets with paddy straw or leaves of custard apple as cushioning material and transported to markets. Modified atmosphere packaging (MAP) is intended to create an appropriate gaseous atmosphere around a commodity packed in film packages to enhance shelf life and conserve the quality of packed produce (Rai et al., 2002). Therefore, it is necessary to investigate the proper method of packaging to enhance the shelf life and conserve the quality of produce.

\section{Materials and Methods}

In the present investigation, packaging material (Polypropylene Bag) is having different number of holes and control treatment without using any packaging material examined for custard apple cv. Balanagar. Experiment was laid in completely randomized block design with three replications and eight treatments in the PostHarvest Technology Laboratory of Department of Horticulture, H. N. B. G. U. Srinagar Garhwal Uttarakhand. In each treatment, 5 fruits were tested and observations were recorded at 4 days interval for physiological loss in weight, total soluble solids and total sugars. The experiment comprises of 08 treatments namely, $\mathrm{T}_{1}$ Packing of fruits in polypropylene bag with 08holes, $\mathrm{T}_{2^{-}}$Packing of fruits in polypropylene bag with 16 holes, $\mathrm{T}_{3}$-Packing of fruits in polypropylene bag with 24holes, $\mathrm{T}_{4}$ - Packing of fruits in polypropylene bag with 32holes, $\mathrm{T}_{5}$ - Packing of fruits in polypropylene bag with 40 holes, $\mathrm{T}_{6}$ - Packing of fruits in polypropylene bag with 48 holes, $\mathrm{T}_{7}$ - Packing of fruits in polypropylene bag without any hole and $\mathrm{T}_{8}$-control (without polypropylene bag).

\section{Results and Discussion}

\section{Physiological loss in weight $(\%)$}

Data presented in table 1 and depicted in Fig. 1 revealed that polypropylene bag with 24holes $\left(\mathrm{T}_{3}\right)$ recorded significantly lowest PLW (1.27\%). Treatment $\left(\mathrm{T}_{8}\right)$ without any packaging material recorded significantly highest PLW $(2.42 \%)$. In the present investigation, the physiological loss in weight in cultivar Balanagar indicates the progress of ripening in climacteric fruits, higher the PLW, more the ripening (Ingale et al., 1982). Among the treatments, the lowest PLW was recorded in polypropylene bags with 24 holes. This may have been resulted from restricted availability of oxygen and $\mathrm{CO}_{2}$ accumulation and consequently reduction in respiration leading to less moisture loss (Heining, 1975). 


\section{Total soluble solids $\left({ }^{0} \mathrm{Brix}\right)$}

Table 2 showed that total soluble solids (TSS) of custard apple fruits cv. Balanagar were significantly differing among the treatments (Fig. 2). Significantly highest TSS was recorded in polypropylene bags with 24 holes $\left(\mathrm{T}_{3}, 25.98\right)$. Significantly lowest TSS was recorded in without packaging $\left(\mathrm{T}_{8}, 20.78\right)$. Significant differences were observed in TSS of custard apple fruits due to storage period. The TSS increased progressively from ' 0 ' day (21.50) to $16^{\text {th }}$ day (29.10) of storage period.

In the present investigation, it was observed that the TSS of custard apple fruits initially increased with increase in storage period. Soluble solids rise continuously with the respiratory increase in annonaceous fruits and reach a maximum after the onset of second respiratory rise (Wills et al., 1984; Tsay and Wu, 1989 and Martinez et al., 1993). The increase in TSS during the initial stages may be attributed to the conversion of starch and other polysaccharides into soluble forms of sugars (Mukherjee and Dutta, 1967 and Satyan et al., 1992). The increase in TSS was gradual in custard apple fruits stored at $15^{\circ} \mathrm{C}$ and $20^{\circ} \mathrm{C}$ (Prasanna et al., 2000).

\section{Total sugars (\%)}

The data on total sugars of custard apple fruits cv. Balanagar are presented in Table 3 and depicted in Fig. 3. Data showed there were significant differences among the treatments with respect to total sugars. Highest total sugar was recorded in polypropylene bags with 24 holes $\left(T_{3}, 20.59\right)$, which was significant among the treatments; lowest total sugar was recorded in control $\left(\mathrm{T}_{8}, 16.66\right)$.Significant differences were observed in total sugars of custard apple fruits due to storage period.

On the basis of above findings, it may be concluded that the treatment $\mathrm{T}_{3}$ (Polypropylene bag with 24 holes) is superior over other treatments for the improvement of the shelf life of custard apple under subtropical conditions of Garhwal hills.

Table.1 Effect of polypropylene bag on physiological loss in weight (\%) of custard apple fruits

\begin{tabular}{|c|c|c|c|c|c|}
\hline \multirow{2}{*}{ Treatments } & \multicolumn{4}{|c|}{ Days } & Mean \\
\cline { 2 - 6 } & 4 & 8 & 12 & 16 & \\
\hline $\mathbf{T}_{\mathbf{1}}$-Polypropylene bag with 08 holes & 0.66 & 1.10 & 1.42 & 2.08 & 1.31 \\
\hline $\mathbf{T}_{\mathbf{2}}$-Polypropylene bag with 16 holes & 0.61 & 1.12 & 1.64 & 2.43 & 1.45 \\
\hline $\mathbf{T}_{\mathbf{3}}$-Polypropylene bag with 24 holes & 0.60 & 1.06 & 1.41 & 2.02 & 1.27 \\
\hline $\mathbf{T}_{\mathbf{4}}$-Polypropylene bag with 32 holes & 0.60 & 1.25 & 1.69 & 3.25 & 1.70 \\
\hline $\mathbf{T}_{\mathbf{5}}$-Polypropylene bag with 40 holes & 0.74 & 1.36 & 1.78 & 2.49 & 1.60 \\
\hline $\mathbf{T}_{\mathbf{6}}$-Polypropylene bag with 48 holes & 0.80 & 1.26 & 1.81 & 2.18 & 1.51 \\
\hline $\mathbf{T}_{\mathbf{7}}$-Polypropylene bag without holes & 0.60 & 1.32 & 2.49 & 4.31 & 2.18 \\
\hline $\mathbf{T}_{\mathbf{8}}$-Control (without Polypropylene & 0.81 & 1.39 & 2.81 & 4.66 & 2.42 \\
\hline bag) & & & & & \\
\hline S.Em \pm & & & $\mathbf{0 . 3 8}$ & & \\
\hline CD at $\mathbf{( 0 . 0 5 )}$ & & & & & \\
\hline
\end{tabular}


Table.2 Effect of polypropylene bag on total soluble solids ( ${ }^{\circ}$ Brix) of custard apple fruits

\begin{tabular}{|c|c|c|c|c|c|c|}
\hline \multirow{2}{*}{ Treatments } & \multicolumn{5}{|c|}{ Days } & Mean \\
\cline { 2 - 7 } & 0 & 4 & 8 & 12 & 16 & \\
\hline $\mathbf{T}_{\mathbf{1}}$-Polypropylene bag with 08 holes & 18.80 & 18.50 & 22.30 & 24.50 & 27.30 & 22.28 \\
\hline $\mathbf{T}_{\mathbf{2}}$-Polypropylene bag with 16 holes & 19.50 & 21.30 & 24.10 & 27.10 & 28.50 & 24.10 \\
\hline $\mathbf{T}_{\mathbf{3}}$-Polypropylene bag with 24 holes & 21.50 & 22.30 & 28.90 & 28.10 & 29.10 & 25.98 \\
\hline $\mathbf{T}_{\mathbf{4}}$-Polypropylene bag with 32 holes & 20.30 & 21.90 & 25.90 & 26.30 & 28.90 & 24.66 \\
\hline $\mathbf{T}_{\mathbf{5}}$-Polypropylene bag with 40 holes & 19.90 & 21.50 & 24.80 & 26.30 & 28.30 & 24.16 \\
\hline $\mathbf{T}_{\mathbf{6}}$-Polypropylene bag with 48 holes & 19.10 & 21.30 & 22.90 & 25.30 & 28.30 & 23.38 \\
\hline $\mathbf{T}_{\mathbf{7}}$-Polypropylene bag without holes & 17.90 & 21.10 & 21.30 & 24.30 & 28.10 & 22.54 \\
\hline $\mathbf{T}_{\mathbf{8}}$-Control (without Polypropylene bag) & 17.10 & 20.50 & 20.70 & 22.30 & 23.30 & 20.78 \\
\hline S.Em \pm & \multicolumn{5}{|c|}{$\mathbf{0 . 0 5}$} \\
\hline CD at (0.05) & \multicolumn{7}{|c|}{$\mathbf{1 . 0 0}$} \\
\hline
\end{tabular}

Table.3 Effect of polypropylene bag on total sugars (\%) of custard apple fruits

\begin{tabular}{|c|c|c|c|c|c|c|}
\hline Treatments & \multicolumn{5}{|c|}{ Days } & Mean \\
\cline { 2 - 7 } & 0 & 4 & 8 & 12 & 16 & \\
\hline $\mathbf{T}_{\mathbf{1}}$-Polypropylene bag with 08 holes & 9.49 & 15.73 & 20.46 & 21.85 & 22.62 & 18.03 \\
\hline $\mathbf{T}_{\mathbf{2}}$-Polypropylene bag with 16 holes & 9.77 & 16.91 & 17.89 & 21.49 & 24.34 & 18.08 \\
\hline $\mathbf{T}_{\mathbf{3}}$-Polypropylene bag with 24 holes & 10.54 & 19.87 & 20.86 & 25.81 & 25.91 & 20.59 \\
\hline $\mathbf{T}_{\mathbf{4}}$-Polypropylene bag with 32 holes & 9.81 & 18.68 & 19.87 & 24.34 & 25.30 & 19.60 \\
\hline $\mathbf{T}_{\mathbf{5}}$-Polypropylene bag with 40 holes & 9.56 & 18.68 & 18.97 & 23.45 & 24.34 & 19.00 \\
\hline $\mathbf{T}_{\mathbf{6}}$-Polypropylene bag with 48 holes & 9.56 & 16.92 & 18.97 & 21.49 & 22.90 & 17.96 \\
\hline $\mathbf{T}_{\mathbf{7}}$-Polypropylene bag without holes & 9.49 & 16.32 & 18.68 & 21.49 & 21.85 & 17.57 \\
\hline $\mathbf{T}_{\mathbf{8}}$-Control (without Polypropylene bag) & 8.89 & 14.83 & 17.89 & 19.83 & 21.85 & 16.66 \\
\hline S.Em \pm & \multicolumn{7}{|c|}{0.11} \\
\hline
\end{tabular}

Fig.1 Effect of polypropylene bag on physiological loss in weight (\%) of custard apple fruits

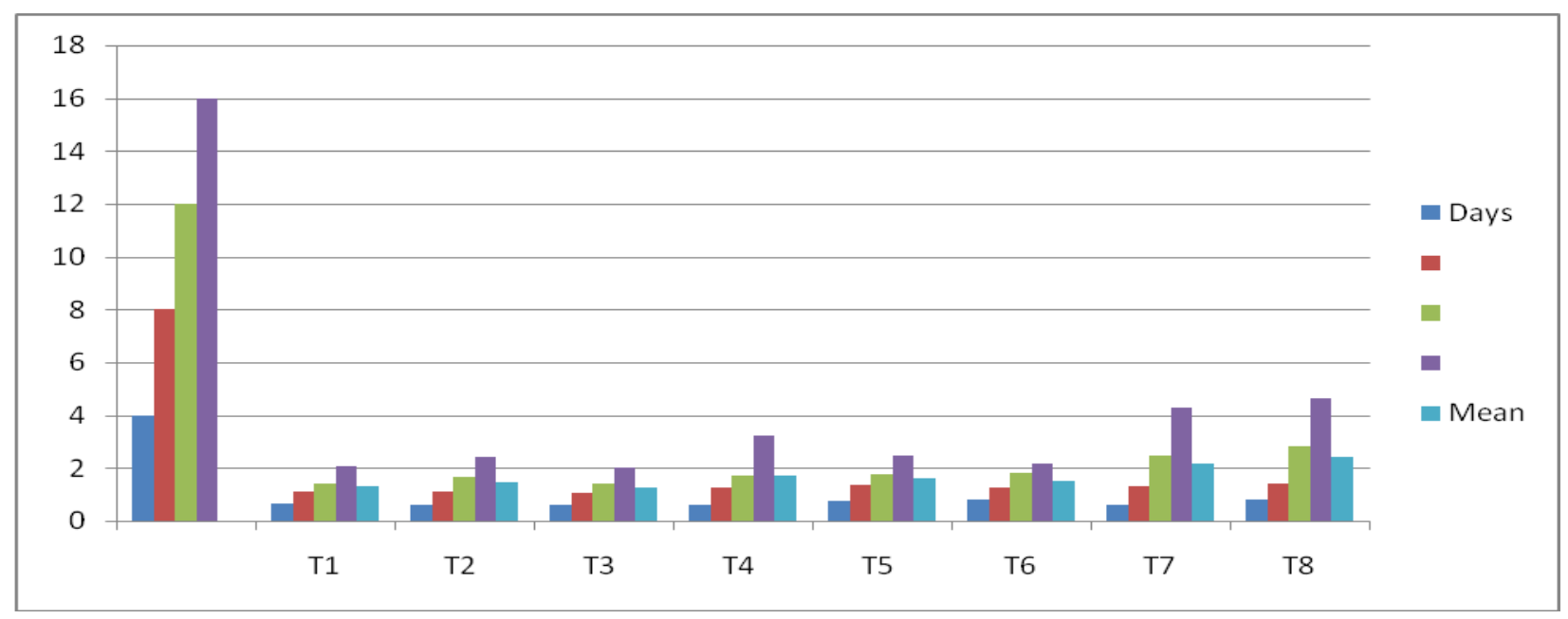


Fig.2 Effect of polypropylene bag on total soluble solids ( ${ }^{\circ}$ Brix) of custard apple fruits

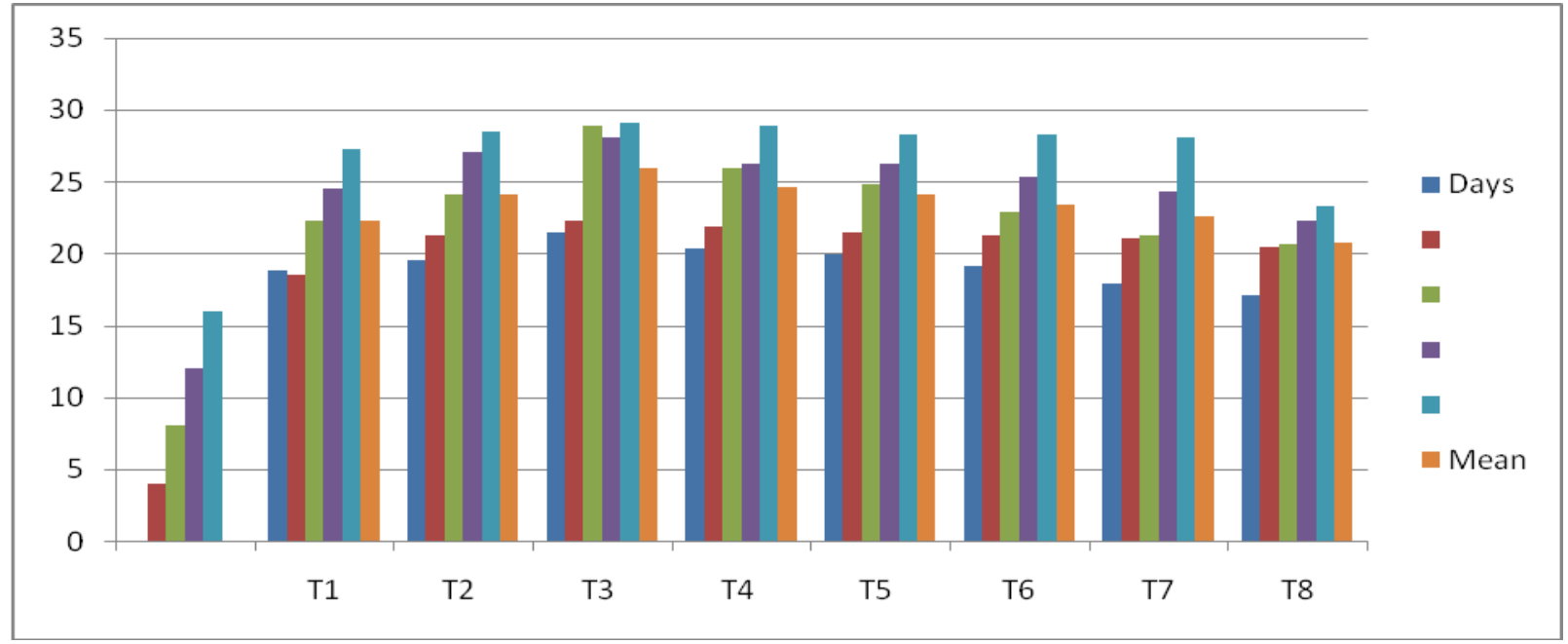

Fig.3 Effect of polypropylene bag on total sugars (\%) of custard apple fruits

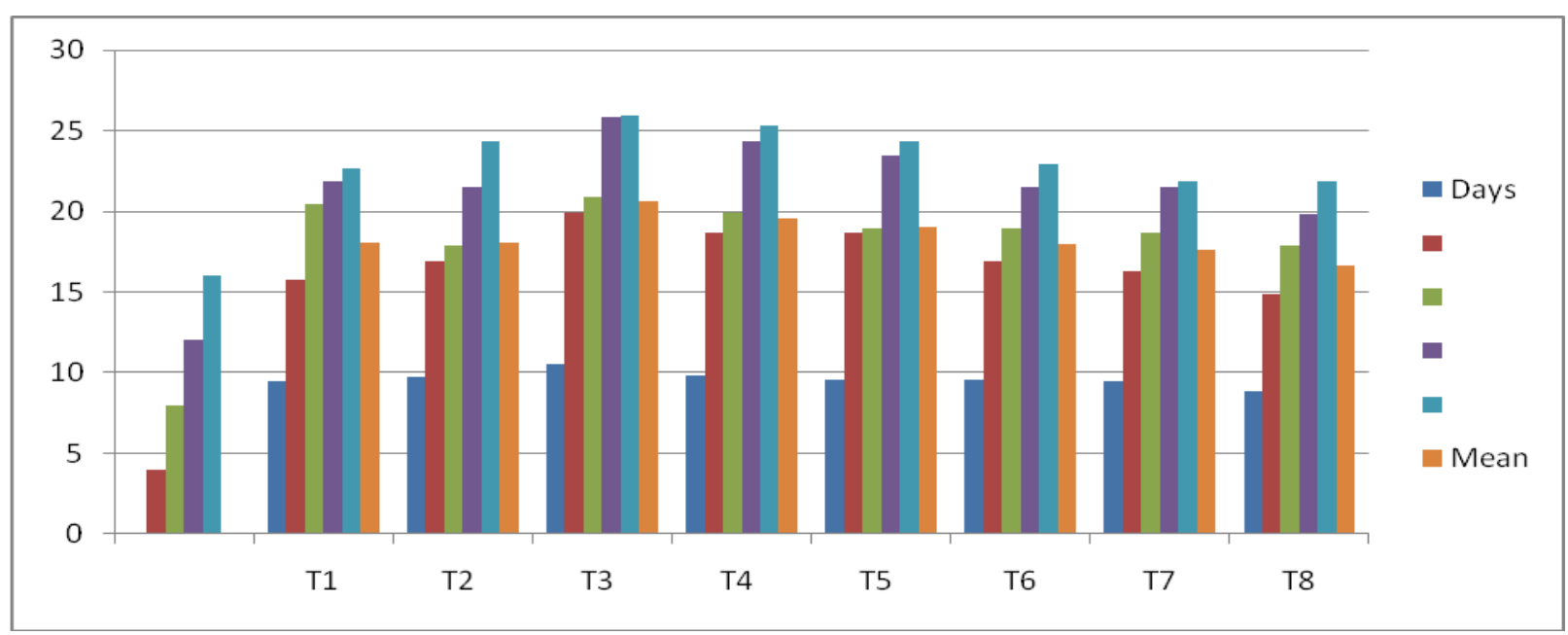

\section{References}

Beerh, O. P, 1972. Consolidated project report on utilization of custard apple. CFTRI. Exp. Station, Hyderabad.

Gautam, B and G. Neeraja, 2005. Effect of polythene bag storage on shelf life and quality of Banganapalli mangoes. Orissa Journal of Horticulture33 (2): 89-93.

Heining, Y. S, 1975. Storage stability and quality of produce in polythene film. In post harvest biology and handling of fruits and vegetables. (eds) by Haard $\mathrm{N}$
F and Salukhe D K. pp 144-152.

Ingale, G. S., D. M. Khedkar, R. S. Dabhade, 1982. Physico-chemical changes during growth of sapota fruit (Achras sapota L.). Indian Food Packer36: 8694.

Jalikop, S. H. 2006. Custard apple, In: Hand book of Horticulture. (Ed. Chadha $\mathrm{K}$ L,)ICAR pub, New Delhi, India, pp 109-114.

Manica, I. 1994. Fruitcultura. Cultivo das Anonaceas Ata, Cherimolia, Graviola. Porto Alegre: Evangraf.

Mukherjee and Dutta, 1967.Delaying of 
postharvest ripening of mango by postharvest treatments of Calcium. Tropical Horticulture68: 151-153.

Rajput, C. B. S. 1985. Custard apple, In: Fruits of India-Tropical and subtropical, (Ed. T K Bose,) Nayaprakash pub, Calcutta, India, pp 479-486.

Reddy, B. S. 2000. Crop improvement and standardization of propagation techniques in sitaphal.

Salunkhe, D. K., S. S. Kadam, 1995. Handbook of Fruit Science and Technology, Ed. Marcel Dekker, Inc., New York, pp. 81-83.

Satyan, S., K. J.Scott, D. Graham, 1992. Storage of banana bunches in sealed polyethylene tubes. Journal of
Horticulture Science.67: 251-53.

Tsay, L. M., M. C. Wu, 1989. Studies on the post-harvest physiology of sugar apple ActaHorticulturae, 258: 287-294.

Wills, R. B. H., A. Poi, H. Greenfield, C. J. Rigency, 1984.Postharvest changes in fruit composition of Annonaatemoya during ripening and effects of storage temperature on ripening. Hort. Sci.19: 1, 96-97.

Wills, R. B. H., M. A. Warton, D. M. D. N. Mussa, L. P. Chew, 2001. Ripening of climacteric fruits initiated at low ethylene levels. Australian Journal of Experimental Agriculture, 41 (1):8992.

\section{How to cite this article:}

Tanuja, D. K. Rana and Rathi, D. S. 2021. Shelf Life Enhancement of Custard Apple (Annona squamosa L.) under Sub-Tropical Conditions of Garhwal Hills. Int.J.Curr.Microbiol.App.Sci. 10(02): 3175-3180. doi: https://doi.org/10.20546/ijcmas.2021.1002.348 